\title{
Archaeological Testing of the Cave at Site 41BX22 Bexar County, Texas
}

Glenn T. Goode

Follow this and additional works at: https://scholarworks.sfasu.edu/ita

Part of the American Material Culture Commons, Archaeological Anthropology Commons, Environmental Studies Commons, Other American Studies Commons, Other Arts and Humanities Commons, Other History of Art, Architecture, and Archaeology Commons, and the United States History Commons

Tell us how this article helped you.

This Article is brought to you for free and open access by the Center for Regional Heritage Research at SFA ScholarWorks. It has been accepted for inclusion in Index of Texas Archaeology: Open Access Gray Literature from the Lone Star State by an authorized editor of SFA ScholarWorks. For more information, please contact cdsscholarworks@sfasu.edu. 


\section{Archaeological Testing of the Cave at Site 41BX22 Bexar County, Texas}

\section{Licensing Statement}

This is a work produced for the Texas Department of Transportation (TxDOT) by the report producer. TxDOT and the report producer jointly own all rights, title, and interest in and to all intellectual property developed under TXDOT's contract with the report producer. The report may be cited and brief passages from this publication may be reproduced without permission provided that credit is given to both TxDOT and the report producer. Permission to reprint an entire chapter, section, figures or tables must be obtained in advance from either the Supervisor of the Archeological Studies Branch, Environmental Affairs Division, Texas Department of Transportation, 125 East 11th Street, Austin, Texas, 78701 or from the report producer. 


\section{ARCHAEOLOGICAL TESTING OF THE CAVE AT SITE $41 \mathrm{BX} 22$ \\ BEXAR COUNTY, TEXAS}

B y

Glenn T. Goode

Texas

State Department of Highways and Public Transportation

Highway Design Division

January 1985 


\begin{abstract}
The Rogers Site, 41BX22, is located on the east bank of a tributary to Salado Creek in northern Bexar County and has three major occupation or activity areas: a terrace-bench site with a burned rock midden, a small cave, and quarry areas on the bluff overlooking the bench and cave sites.

The terrace site was test-excavated by students in the mid-1960s. Primarily Late Prehistoric and Late Archaic materials were recovered with the Middle Archaic and possibly the Early Archaic being represented. Relic hunters have since thoroughly destroyed this portion of the site which lies just north of the FM 1604 right-of-way.

This report deals only with the small cave, located 40 meters downstream from the terrace site. The cave was tested by the State Department of Highways and Public Transportation in response to highway improvements along FM 1604. The test was brief, aimed at determining the depth and age of the cultural deposit. No features and only two diagnostic artifacts were found. Unfortunately, with this limited evidence, a confident statement regarding the time range of occupation cannot be made. The small charcoal samples which were collected could be helpful in resolving the time problem.
\end{abstract}


Archaeological Site 41BX22, the Rogers Site, was initially recorded by Daniel E. Fox in 1966. It subsequently came under the jurisdiction of the State Department of Highways and Public Transportation (SDHPT) as part of an improvement program for FM 1604 which called for widening of the existing right-of-way. Testing was conducted by Glenn T. Goode of the SDHPT Archaeology Section and two employees of the SDHPT San Antonio office during the period September 5 through September 17, 1984. An estimated 215 personhours were expended during the field work on this project. Testing was conducted in accordance with Procedures for the Protection of Historic and Cultural Properties (36 CFR, Part 800), procedures prescribed by law and endorsed by the Federal Highway Administration. The testing objectives were to determine cultural content and the potential for eligibility for nomination to the National Register of Historic Places.

All cultural material recovered is the property of the State of Texas. The SDHPT will serve as a temporary repository for all recovered materials as well as all maps, photographs, field notes, and other written documentation until final disposition of these materials in a proper curational facility is determined. 


\section{SITE DESCRIPTION}

The Rogers Site is located in north-central Bexar County a the $\mathbb{M}$ 1604 crossing of Salado Creek (Fig. 1). The site extends from 25 meters to about 150 meters north of the road, along the eastern margin of the creek. Several areas of occupation and quarry activity make up the total site complex of 41BX22. These areas occupy four distinct geologic features.

Sparse, widely scattered lithic debitage and burned rock occur along a terrace which is situated between Salado Creek and a small branch tributary. The narrow branch separates the terrace from a 10 meter high limestone bluff which forms the east bank of Salado Creek. Chert outcrops atop the bluff and lithic debris are scattered across an area of 100 meters by 50 meters.

A the base of the bluff is a small cave, lying 2.5 meters above the bed of the branch (Fig. 2). The cave opens on a narrow bench, 5 to 10 meters wide, which is the east bank of the small branch creek. The bench continues northward to its widest point 40 to 80 meters north of the cave. In this area beyond the right-of-way were stratified cultural deposits which were tested in 1966 (Daniel E. Fox, personal communication, 1984). Subsequent pothunting has apparently destroyed most of this site. A small burned rock midden on the bench is less disturbed but is eroding into the branch.

The cave entrance, oval in shape, is 3 meters wide and 1.3 meters high. Immediately outside the cave to the north side is a low mound of reddish brown soil which contains flake debitage. This soil was removed from the cave by relic collectors--the fill (50 am to $75 \mathrm{~cm}$ in thickness) was removed for a distance of 3.5 meters to 4.0 meters into the cave. The cave is fairly straight and of roughly even width (2.0 meters to 2.3 meters) for a distance of 12 meters (Fig. 3). 


\section{This Page Redacted Per THC Policy}




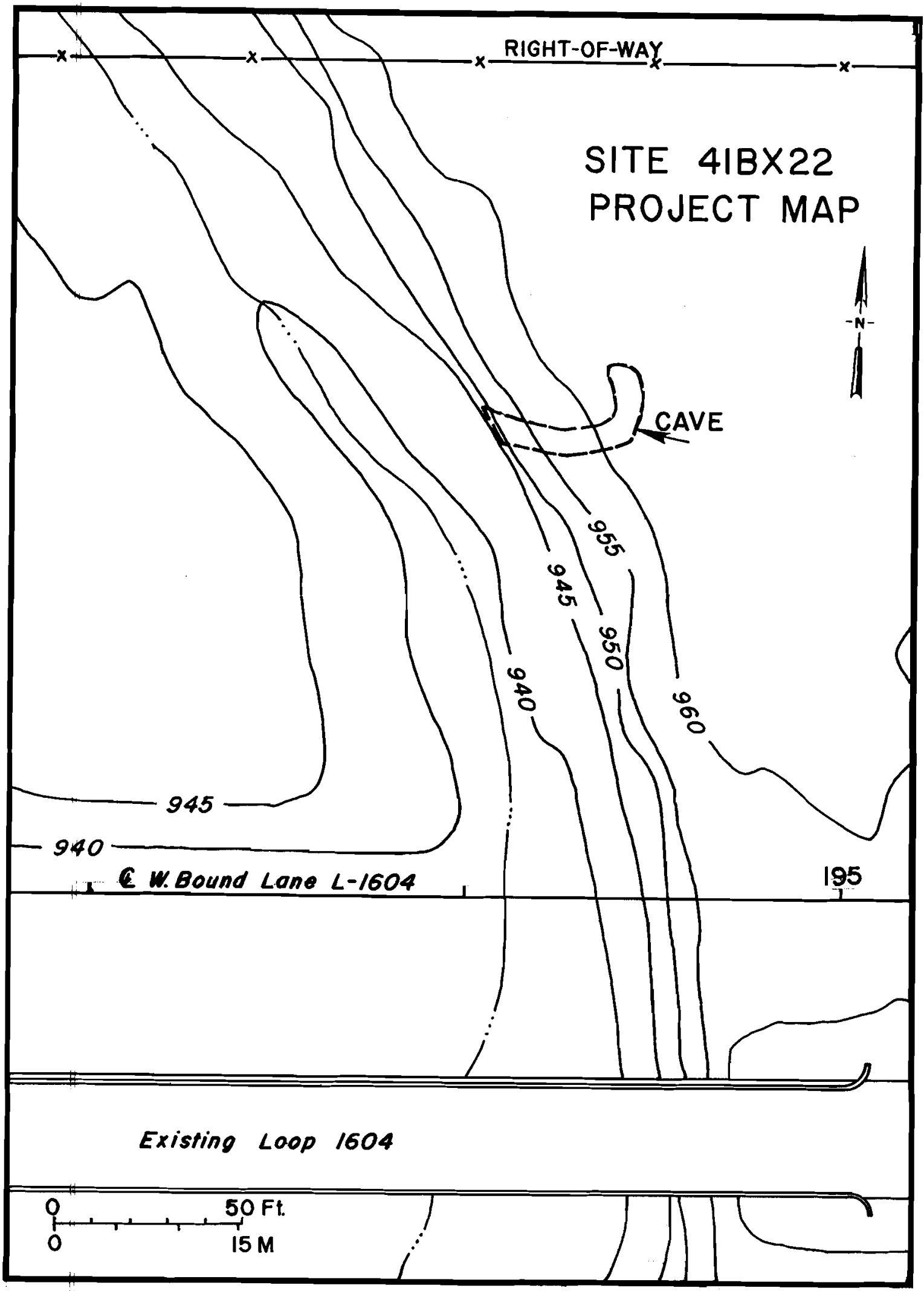

FIGURE 2. Contour map of portion of Site 41BX22 containing cave. 


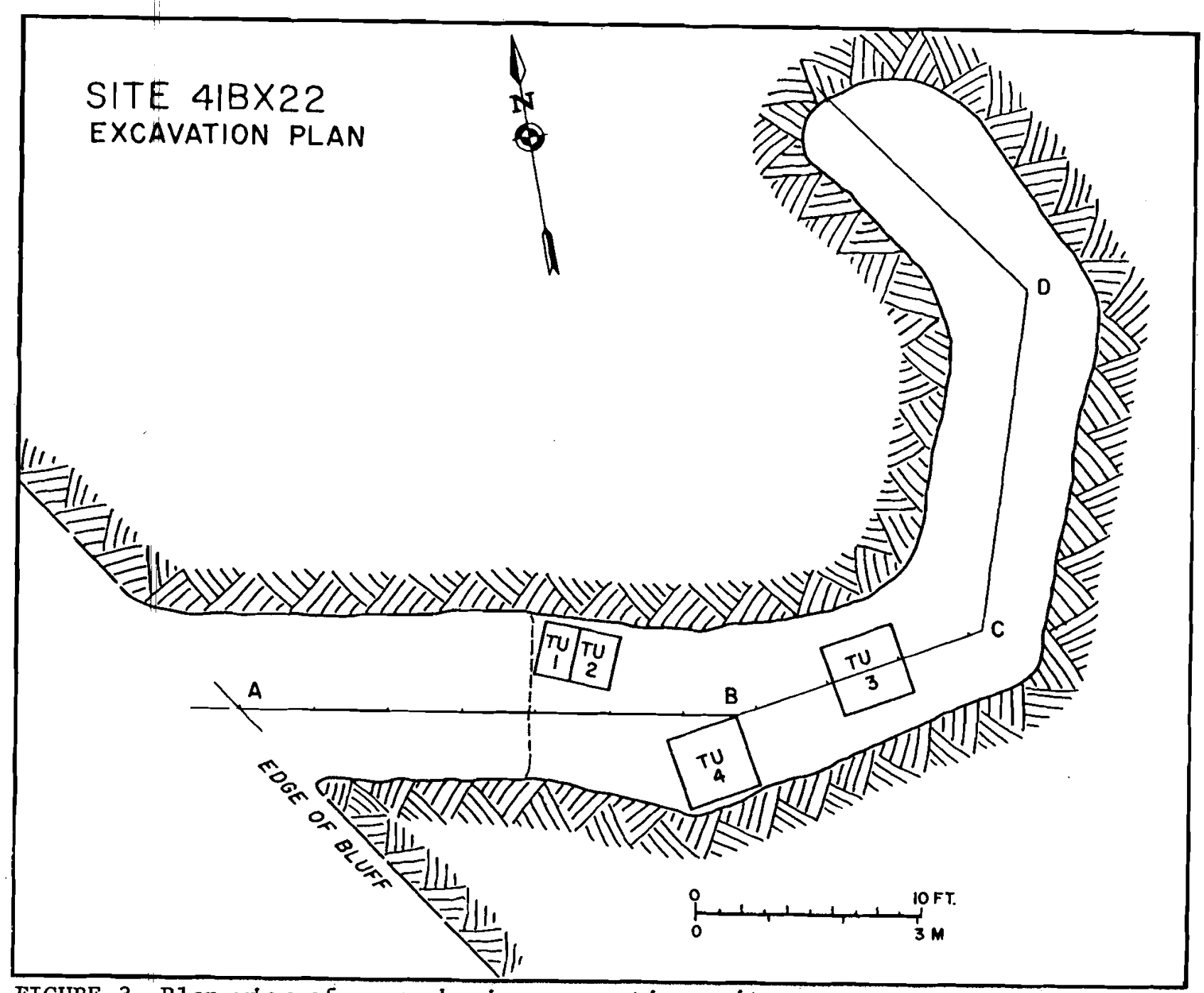

FIGURE 3. Plan view of cave showing excavation units. 
At this point it turns sharply to the north, forming an "L" shape. Except at the two small chimneys located above Test Units 3 and 4, there is an average of only $70 \mathrm{~cm}$ clearance between the cave floor and roof. Clearance decreases somewhat toward the rear, as the cave decreases slightly in width. 


\section{TESTING PROCEDURES}

The cave had been mapped by an SDHPT survey crew prior to the test excavation. To save time, this map and the centerline reference points were used for test unit alignment purposes. A typical excavation grid was not established. Using arbitrary 10 om levels, Test Unit 1 and Test Unit 2 were excavated to determine if the cave contained a cultural deposit. The units were placed at the western edge of the intact deposit--from there to the entrance (3.5 meters to 4.0 meters) the deposit had'been removed by pothunters--and as neat the north wall as was feasible. Their size, $50 \mathrm{~cm}$ by $60 \mathrm{~cm}$ and $50 \mathrm{~cm}$ by $75 \mathrm{~cm}$, was set to accommodate the westward slope of the disturbed surface. Test Unit 2 encountered Zone III soil at $40 \mathrm{~cm}$. Sufficient lithic debitage was found to predict that the cave might contain substantial cultural deposits.

Accordingly, two 1 by 1 meter units were selected for excavation, also in 10 am Levels. Each unit was positioned under a small chimney (75 cm to 1 meter in width) to provide needed space for working. Outside the chimneys, the average floor-to-ceiling clearance was 70 cmor less. Below the first level it was necessary to excavate primarily with small picks and rock hammers, the clay loam deposit being extremely compact and hard. The matrix was carried outside the cave in buckets and screened through .25 in. hardware cloth. All, cultural materials were collected in appropriately labeled bags. 


\section{SOILS}

The soil profile of the cave consists of a 1 meter thick deposit of loam and clay loam, divided into three zones.

Zone $I$ is a gray-brown loam extending from the surface to a depth of $150 \mathrm{r} 20 \mathrm{~cm}$. The upper $10 \mathrm{~m}$ of this soil is dry and powder-like; the lower $10 \mathrm{om}$ is very compact and hard. Pebble-size limestone roof spall is present in small amounts, scattered throughout the matrix. Lithic debitage is widely scattered on the surface and small numbers of artifacts, mostly debitage, are present in Zone I. Small bones and fragments were also present in Zone $I$ of all test units.

Zone I I is a 30 to $50 \mathrm{~cm}$ deposit of brown to light reddish brown clay loam The upper 20 to $30 \mathrm{~cm}$ is dry, extremely compact, and hard. In T estUnit 3 , near 50 am depth, the matrix became slightly damp but remained extremely hard. An increase in roof spall occurred at about the same depth--near $50 \mathrm{~cm}$. In Test Units 3 and 4 , the spall was concentrated under the chimneys, and decreased sharply beyond their perimeters.

Also in Test Unit 3 at the bottom of Level 5 and into Level 6 occurred a 40 to $50 \mathrm{~cm}$ area containing scattered charcoal bits, several burned rock fragments, and small lumps of ash. Roof spall was abundant in this area which occurred under and to the edge of a chimney. Charcoal was also widely scattered across the entire unit. The area containing firedmaterials was not clearly the locus of a fire hearth. Rather, small amounts of all materials were present, all were scattered, and no scorched earth was detected. More likely, this area represented a dumpor scatter from a nearby hearth.

In the test units, the average artifact count per level increased in Zone II. Again, a large majority of the material was lithic debitage. 
Overall, bone numbers were roughly equal per level, with Zone I I having more in Test Unit 3 and Zone I predominant in Test Unit 4.

Zone III is a dull reddish brown clay loam, slightly moist and extremely compact. This matrix, which contains the deepest cultural remains, appeared at $80 \mathrm{~m}$ in Test Unit 3 and 60 to $70 \mathrm{~cm}$ in Test Unit 4. The artifact and bone counts decrease sharply in Zone III, as do the small amounts of charcoal and snails. Boulder-size limestone rocks at the bottom of all units are associated with the cave floor. 


\section{ART IFACTS}

\section{Lithic Analysis}

The lithic artifact inventory is represented by 598 specimens. A large majority of these, 579 specimens, are flakes and fragments of flakes. The balance of the lithic sample includes 14 cores, $1 \mathrm{dart}$ point, 1 preform biface, 2 small biface fragments, and 1 grinding/ smoothing stone.

The chert which served as raw material for tool manufacture was readily available at $41 \mathrm{BX} 22$. This resource is abundant, outcropping in and atop the limestone bluff which forms the eastern bank of Salado Creek

Upon the bluff widely scattered chert quarry debris occurs across at least a 100 meter by 50 meter area, extending northward from the cave area onto private property. Chert cobbles were also observed along the west bank of Salado Creek and in the creek bed. Several other aboriginal quarry sites within a few kilometers of $41 \mathrm{BX} 22$ have been recorded.

Included in the flake debitage are 286 (49\%) specimens which retain the striking platform. Of these, 137 specimens have characteristics of \$oft-hammer percussion, 110 are hard-hammer, and there are 39 flakes whose method of production is undetermined. Although the debitage sample is relatively small, there is sufficient material to indicate that a 11 stages of core and biface reduction were conducted in the cave. Primary, secondary, and interior flakes of the various reduction stages are present, as well as core fragments and a biface preform.

Several blade-like flakes point to skillful reduction of small to large cobble-size cores. Platforms and dorsal scars indicate that the flakes were removed in series by hard-hammer percussion. Six specimens described as flake-blades were found in Test Unit $\mathbf{3}$, in three consecutive levels. 
Two small unidentifiable biface fragments in addition to the preform arethe balance of the biface sample. With this small sample, little canbe said of biface technology or use by the inhabitants of the cave. The sample might indicate that for tasks performed within the cave there was greater reliance on trimmed and unmodified flakes.

Table 1 gives the provenience of all recovered specimens.

\section{Artifact Descriptions}

SPECIMEN A (Fig. 4)

Measurements: Length, $55 \mathrm{~mm}$; width, $27 \mathrm{~mm}$; thickness, $6 \mathrm{~mm}$.

Description: Specimen A is classified as a Bulverde dart point (Suhm and Jelks 1962). It has a triangular blade with a leftedge, alternate bevel produced by resharpening. The shoulders have been partially removed by sharpening and damage. The wedge-shaped stem contracts slightly to a straight, thin base. Final basal thinning involved the removal of two large pressure flakes which terminated near the shoulder area.

Provenience: This biface was found $5 \mathrm{~cm}$ east of Test Unit 3, the basal edge barely protruding above the surface.

SPECIMEN B (Fig. 4)

Measurements: Length, $40 \mathrm{~mm}$; width, $25 \mathrm{~mm}$; thickness, $4 \mathrm{~mm}$.

Description: Bifacial pressure-trimming along two edges of this thin, triangular, soft-hammer flake formed a sharpened but incomplete point. This is possibly the initial stage of an arrowpoint preform.

Provenience: Test Unit 4, Level 2. 
TABLE 1. Provenience of artifacts.

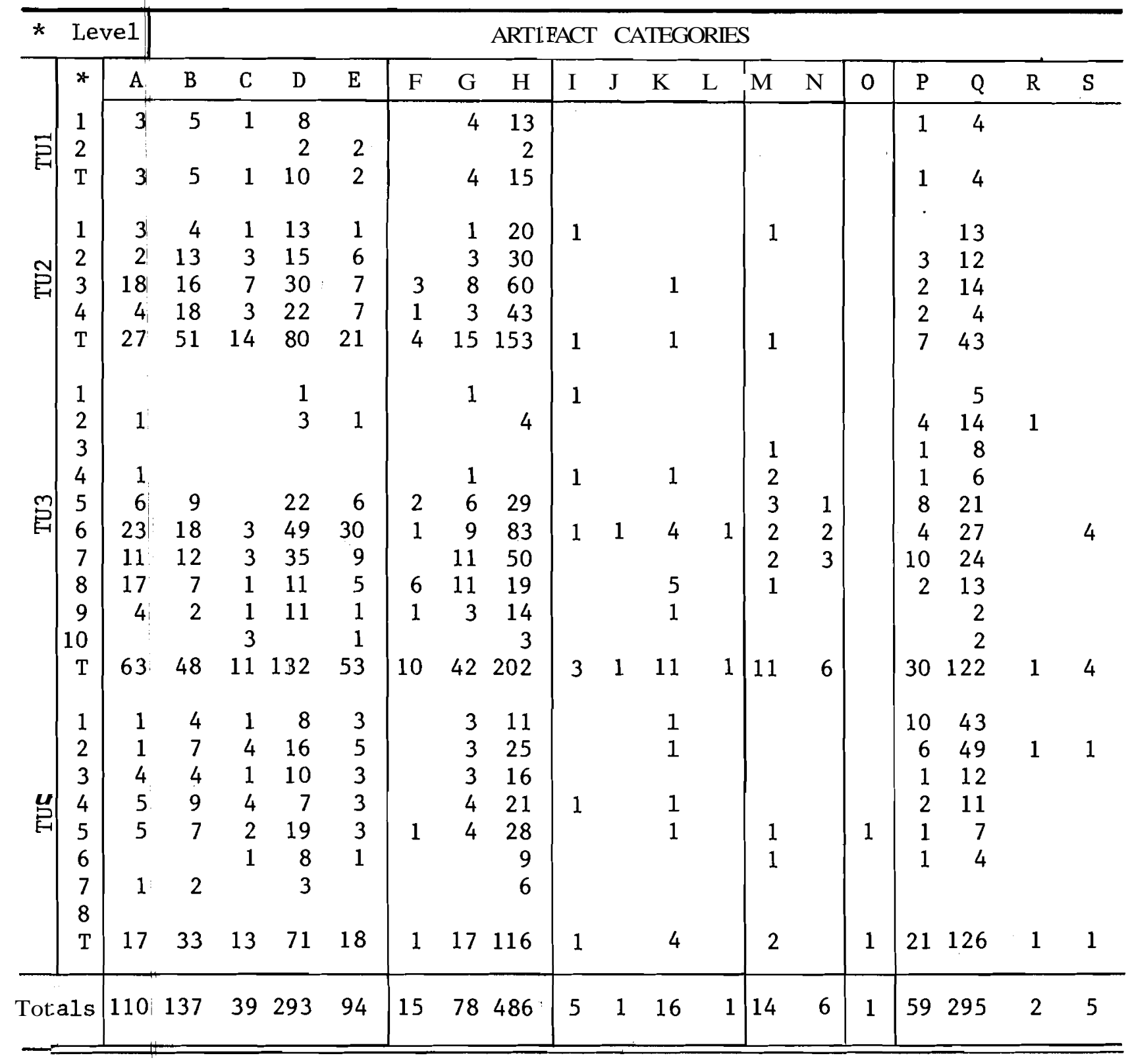

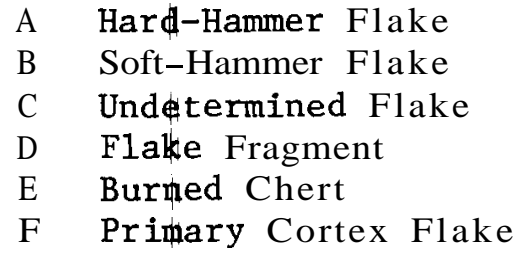

G Secondary Cortex Flake

$\mathrm{H}$ Interior Flake

I Biface

J Uniface

K Flake Tool

L Burin Spal1
Core

Flake-Blade

Ground Stone

Identified Bone

Unidentified Bone

Bone Tool

Mussel Shell 


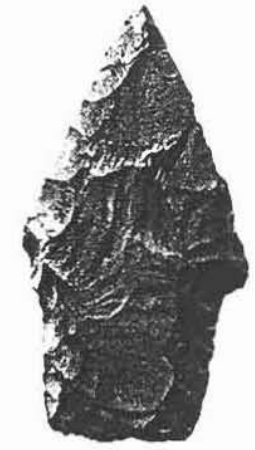

A

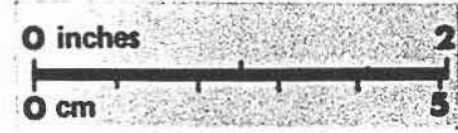

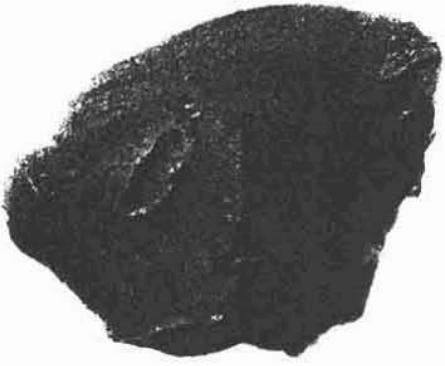

C

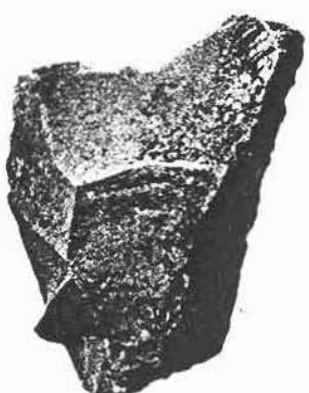

D

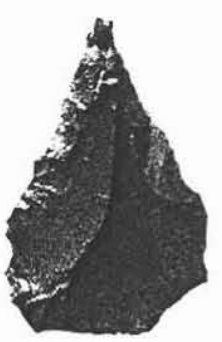

B
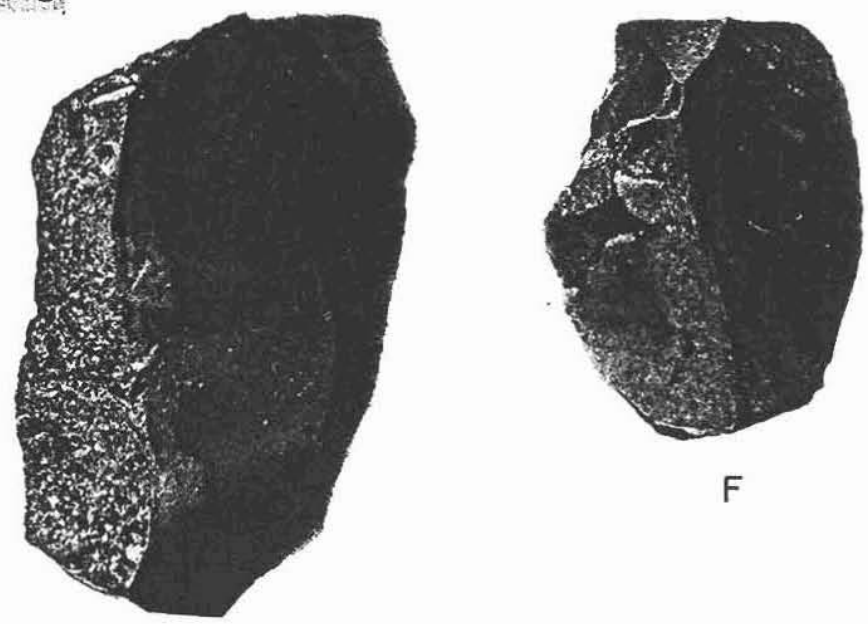

$E$

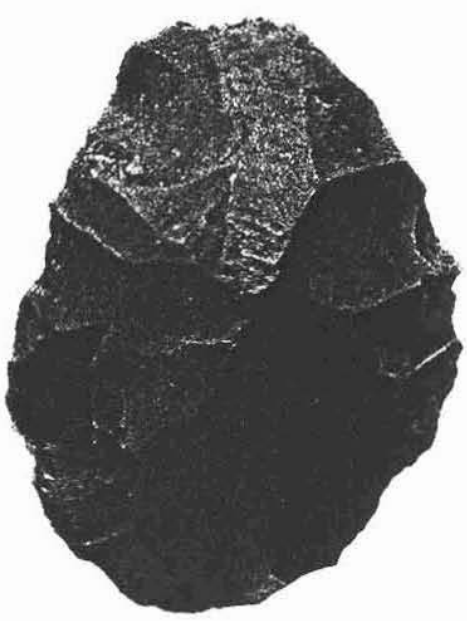

G

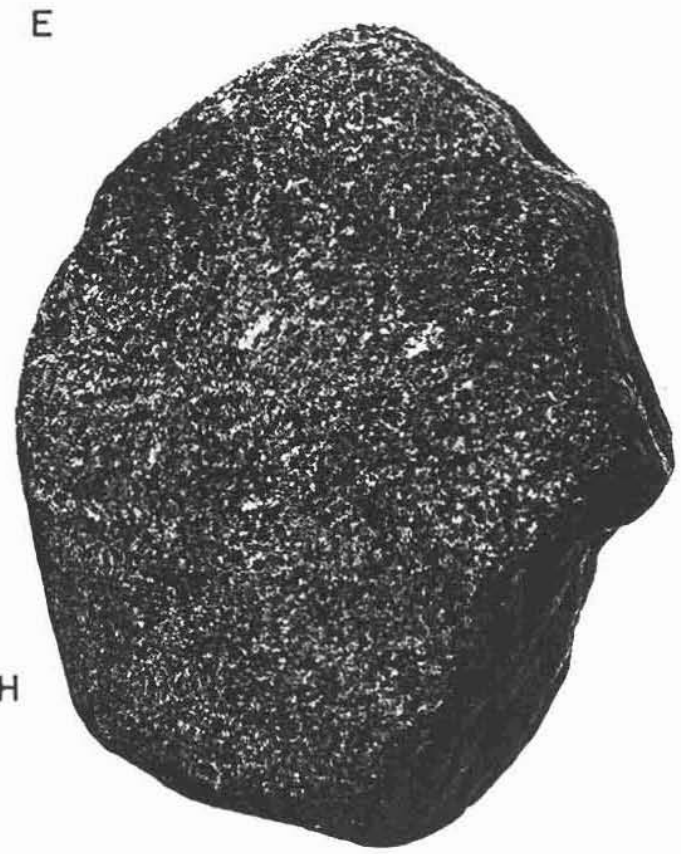

FIGURE 4. Artifacts from Site 41BX22. A, Bulvexde dart point; B, possible arrowpoint preform; C,D,F, utilized flakes; E, flake-blade; $G$, initial stage biface; $\mathrm{H}$, ground stone. 
SPECIMEN C (Fig. 4)

Description: This hard-hammer flake terminated with a rolled-up edge similar to a hinge fracture, producing a working edge along the dorsal surface with an angle of $70^{\circ}$. Continuous moderate to heavy nicking along the edge indicates repeated use, probably in scraping and shaving both hard and soft materials.

Provenience: Test Unit 3, Level 9.

SPECIMEN D (Fig. 4)

Description: The thin distal edge of this hard-hammer flake is nicked and blunted, possibly from cutting hard substances. The original edge angle was about $30^{\circ}$.

Provenience: Test Unit 3, Level 8.

SPECIMEN E (Fig. 4)

Description: Opposing ends of the core are present on this flakeblade. Both surfaces were platforms, with a series of at least four flake-blades removed. The right lateral edge is sharp and has discontinuous minute nicking. This piece could have been used as a cutting tool.

Provenience: Test Unit 3, Level 5.

\section{SPECIMEN F (Fig. 4)}

Description: Unifacial chipping at the juncture of the distal and 1 eft lateral edges produced a $75^{\circ}$ bit on this hard-hammer flake. The working edge indicates possible use as a shaving/ planing tool.

Provenience: Test Unit 4, Level 4. 
SPECIMEN G (Fig. 4)

Description: Both faces of this large flake were partially reduced, giving it the appearance of an initial stage biface. It lacks any well formed working edge, has an overall unfinished appearance, and does not appear to have been a functional tool.

Provenience: Test Unit 3, Level 4.

SPECIMEN H (Fig. 4)

Measurements: Length, $95 \mathrm{~mm}$; width, $78 \mathrm{~mm}$; thickness, $40 \mathrm{~mm}$; weight, $390 \mathrm{gr}$.

Description: This subovoid-shaped limestone cobble has a boatlike shape in cross-section. The two slightly rounded to flat faces meet forming a "V"-shaped, rounded edge. The opposing edge is flat and $40 \mathrm{~mm}$ thick. Both faces are moderately smoothed and covered with straight scratches, oriented in various directions. This stone was apparently used in grinding/smoothing tasks.

Provenience: Test Unit 4, Level 5.

SPECIMEN A (Fig. 5)

Description: Both lateral edges of this hard-hammer flake are thin and sharp, and exhibit areas of continuous nicking which have blunted the original edge angles of $35^{\circ}$ to $40^{\circ}$. Specimen A may have served in both cutting and shaving activities.

Provenience: Test Unit 3, Level 8. 


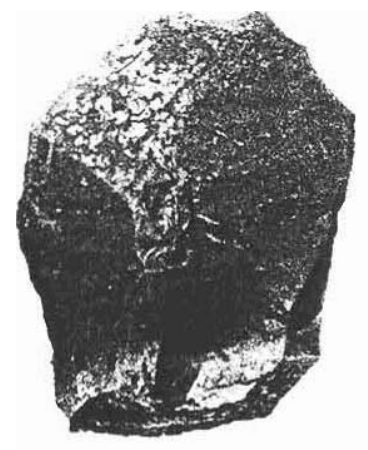

A

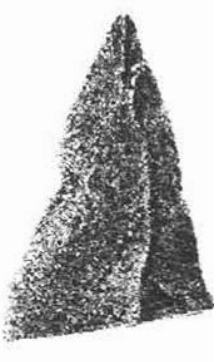

B

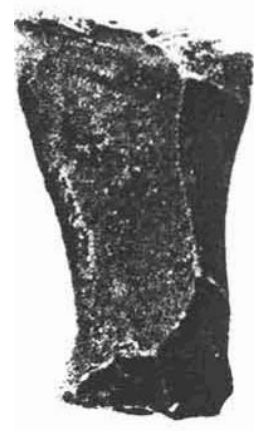

$\mathrm{C}$

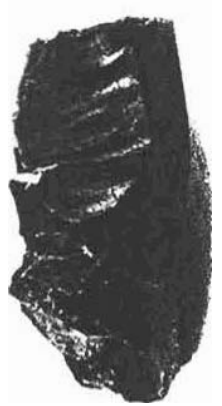

D
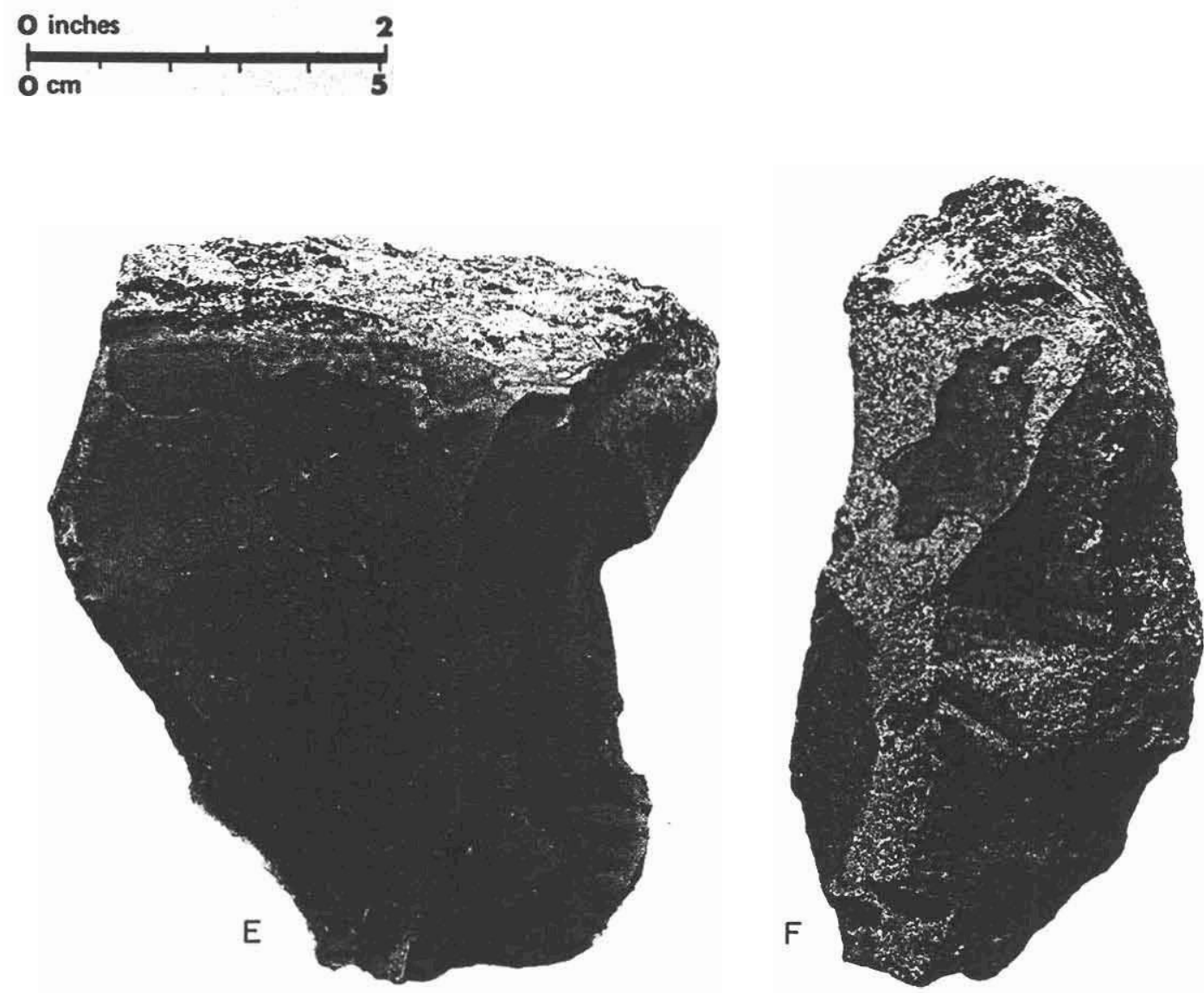

FIGURE 5. Artifacts from Site 41BX22. A-C, F, utilized flakes; D, flakeblade; E, modified flake. 
SPECIMEN B (Fig. 5)

Description: This thin, pointed flake has sharp edges with edge angles of less than $35^{\circ}$. Both edges have nicking and crushing. Possible use as a cutting tool is indicated.

Provenience: Test Unit 3, Level 6.

SPECIMEN C (Fig. 5)

Description: This hard-hammer flake split longitudinally from the point of percussion. The recurved left lateral edge is sharp, with the edge angle ranging from $35^{\circ}$ to $55^{\circ}$. Light nicking and light polish indicate possible use as a cutting tool.

Provenience: Test Unit 4, Level 5.

SPECIMEN D (Fig. 5)

Description: Specimen D is a short, relatively thick flake-blade produced by hard-hammer percussion. On the dorsal surface are five parallel scars produced by flakes originating from the same platform. The first two indicate that fairly long, thin flakeblades were produced; but the latter three were short hinge or step fracture failures, failures at least partly due to striking too near the platform edges. The left lateral edge is strong and relatively sharp with an angle of $60^{\circ}$. Continuous moderate to heavy nicking and/or inexpert trimming have thoroughly dulled the edge. This piece may have served in heavy cutting operations.

Provenience: Test Unit 3, Level 6.

SPECIMEN E (Fig. 5)

Description: The left lateral edge of this large hard-hammer sequence flake has continuous nicking with an area of trimming 
on the dorsal surface. Some trimming is also present on the ventral surface. An edge angle of $35^{\circ}$ to $40^{\circ}$ and a strong keen edge made this specimen a good cutting tool. Apparently it was used in some heavy cutting activities. Dorsal scars reveal that two large flakes had been removed, the latter being almost the size of this specimen. Well controlled, skillful production of a series of large flakes by hard-hammer percussion is indicated by this specimen.

Provenience: Test Unit 3, Level 4.

SPECIMEN F (Fig. 5)

Description: The central portion along the left lateral edge of this primary hard-hammer flake has use damage in the form of continuous nicking. This damage of the thin edge and edge angle of $40^{\circ}$ indicate use as a cutting tool. A single flake scar on the dorsal surface indicates that, prior to the removal of Specimen F, a flake of comparable size was removed from the same platform. Specimen $F$ is another example of skillful reduction of large cobble size lithic resources.

Provenience: Test Unit 3, Level 6.

Fauna

A total of 355 bones and fragments, mostly fairly well preserved, was recovered from the cave. One antler fragment was also found. A large majority of the bone sample was too small or fragmentary for positive species identification. Of the readily identifiable bones are those of deer, cottontail rabbit, snake, wood rat, large turtle, turtle, wolf, opossum, raccoon, medium-size carnivore, fox squirrel, squirrel, and miscellaneous rodents. 
The only species represented by more than two identifications are snake (25 specimens), deer (13 specimens), and cottontail rabbit (11 specimens) .

Two bone tool fragments were recovered.

DEER ULNA

Measurements: Length, $25 \mathrm{~mm}$; width, $9 \mathrm{~mm}$; thickness, $5 \mathrm{~mm}$.

Description: This specimen is a deer ulna fragment, broken in excavation and previously. The surface is highly smoothed with numerous longitudinal scratches and grooves. The tip is blunted by uneven breaks, with light polish present on undamaged surfaces. Possible use as an awl is indicated.

DEER ANTLER TINE

Description: This specimen consists of two fragments of a burned deer antler tine. This fragment of the original tool was broken in excavation and a medial section is missing. Burning resulted in a brown to dark gray-brown color. The surface is polished and shiny, but pitted with small grooves and scratches. The tip, $2.5 \mathrm{~cm}$ in diameter, is blunted and pitted from use. 
The cave at $41 \mathrm{BX} 22$ is a small but integral component of the total site complex. Other prominent elements are a stratified terracebench site, including a burned rock midden, and widespread quarry areas. Findings from the terrace indicate a long period of occupation, perhaps beginning in the Early Archaic (Daniel E. Fox, personal communication, 1984). Heaviest occupations appear to have occurred in Late Archaic through Late Prehistoric times, an assessment based on projectile point chronology (Daniel E. Fox, personal communication, 1984).

The brief test excavation of the cave did not produce sufficient data, in the form of diagnostic artifacts, to date the span of occupation. A single diagnostic projectile point--Bulverde type--was found protruding from the surface near Test Unit 3 . If this point were in an undisturbed context, the entire deposit should be of Middle Archaic or greater age. This age would seem to be unlikely, however, in view of the findings from the terrace-bench site north of the cave. There, by far the more intensive occupations were of Late Archaic and Late Prehistoric age. And, it is probable that the principal occupation of the cave occurred during these later periods. The Bulverde point, then, is thought to be of questionable provenience, perhaps brought into the cave by Late Prehistoric inhabitants.

A Late Prehistoric Occupation could be expected since caves, shelters, and sinkholes of the area, if occupied, typically have a Late Prehisoric component. The possible arrowpoint preform which would indicate a Late Prehistoric occupation occurred in the upper $20 \mathrm{~cm}$ of the deposit. № other datable materials were found in the upper $20 \mathrm{~cm}$. The small samples of charcoal from the lower 50 am of the deposit, if selected for analysis, could answer questions regarding the time of occupation. 
The test excavation of the cave has produced many questions but few answers about the aboriginal inhabitants. Clearly, $41 B \times 22$ is an important site, having the potential of significantly increasing knowledge of a localized hunting and gathering economy. The sizable artifact assemblage, good preservation of bone and charcoal, and the likelihood of intact features being present are strong points for considering the cave eligible for nomination to the National Register of Historic Places. And, under typical circumstances of SDHPT salvage archaeology, further investigation would have been recommended. However, the cave will not be destroyed by expansion of $\mathrm{FM}$ 1604; it has been selected for preservation rather than excavation. Preservation will be achieved by sealing the entrance with boulders. 
REFERENCES CITED

Fox, Daniel E.

1984 Personal communication. Telephone conversation with

Glenn T. Goode, August 29, 1984.

Suhm, Dee Ann, and Edward B. Jelks

1962 Handbook of Texas Archeology: Type Descriptions.

Texas Archeological Society Special Publication 1 and Texas Memorial Museum Bulletin 4. 


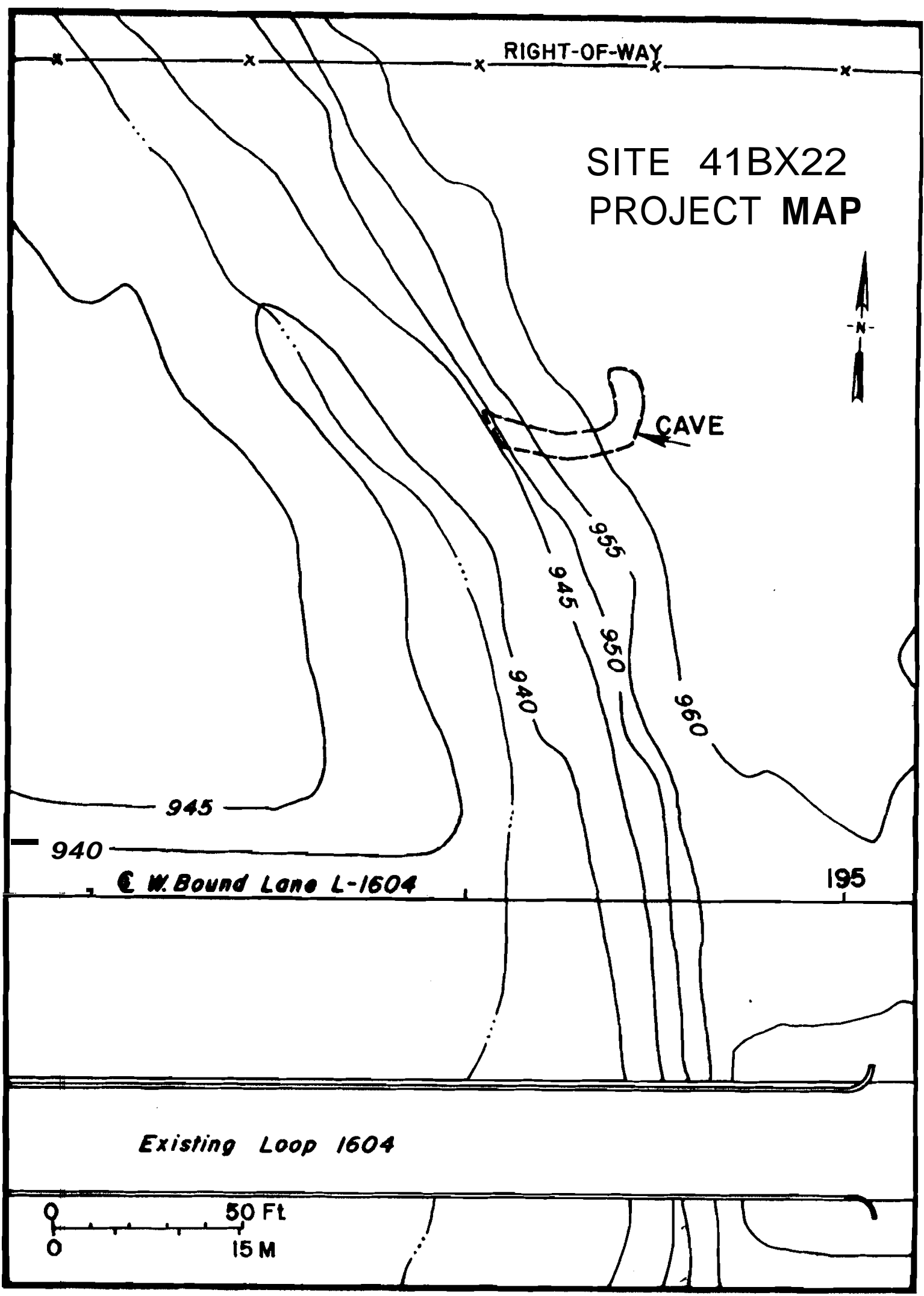




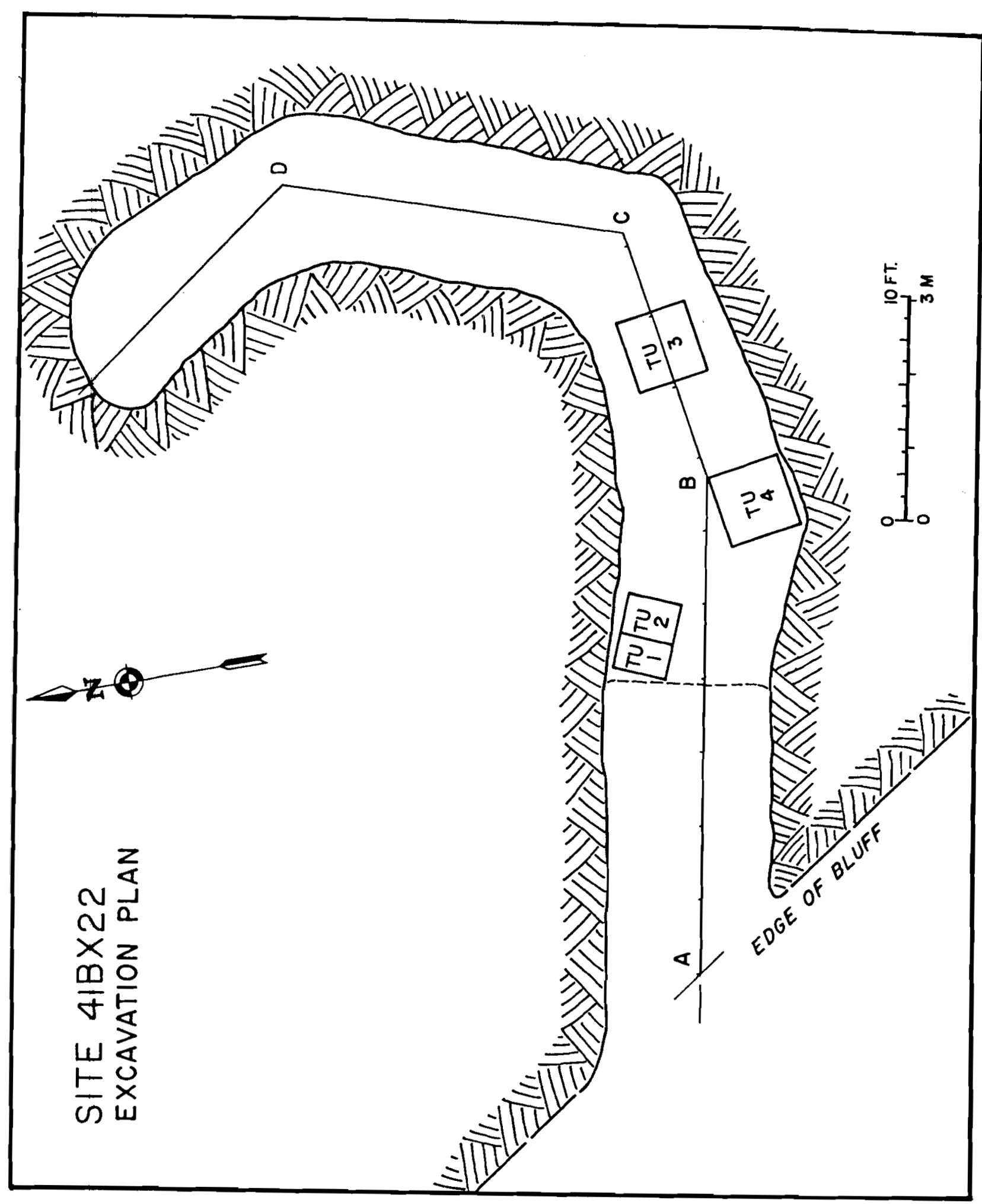

